\title{
Ölüm Zamanı ve Ölüm Nedeni ile İlişkili Olarak Postmortem Göz İçi Sivısında Biyokimyasal İncelemelerin Önemi
}

\section{Importance of Biochemical Analysis of Postmortem Intraocular Fluid Regarding to Time and Cause of Death}

\author{
${ }^{1} U z m$. Dr. Adli Tıр Kurumu, Balıkesir Sube Müdürlüğ̈̈

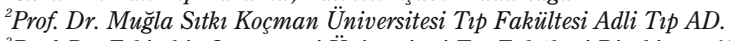 \\ ${ }^{3}$ Prof. Dr. Eskişehir Osmangazi Üniversitesi Tip Fakültesi Biyokimya AD.

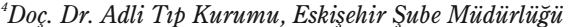 \\ ${ }^{5}$ Prof. Dr. Eskişehir Osmangazi Üniversitesi Tip Fakültesi Biyoistatistik AD.
}

Muharrem Teyin ${ }^{1}$,Yasemin Balcı ${ }^{2}$, Sema Uslu ${ }^{3}$, Kenan Karbeyaz ${ }^{4}$, Kazım Özdamar ${ }^{5}$

\section{Özet}

Giriş: Ölüm zamanı adli makamlarca adli tıp uzmanlarına sıkça sorulan sorulardan biridir. Bu çalışmada, postmortem göz içi sıvı örneklerinde, rutinde kolaylıkla uygulanabilen biyokimyasal testlerin, ölüm nedeni ve postmortem interval ile ilişkisini araştırmak amaçlanmıştır.

Gereç ve Yöntem: Eskişehir Osmangazi Üniversitesi Morgunda otopsisi yapılan ve kesin ölüm zamanı kesin olarak bilinen 100 olgu çalışma kapsamına alınmıştır. Olgular, ölüm zamanı açısından, postmortem intervali 10 saat ve altı, $11-20$ saat ve 20 saatin üstünde olanlar şeklinde 3 gruba ayrılmıştır. Ölüm nedeni açısından travmatik ve travmatik olmayan ölümler olarak 2 gruba ayrılmıştır.

Bulgular ve Sonuç: Sunulan çalışmada, potasyum ve ürik asit ortalama değerleri ile postmortem interval grupları arasında anlamlı bir ilişki olduğu saptanmıştır. Sodyum ve Klorun ortalama değerlerinin travmatik nedenle ölen olgu grubunda diğer gruba göre daha düşük olduğu saptanmıştır.

Anahtar kelimeler: Postmortem biyokimya, Göz içi sıvısı, Ölüm zamanı, Ölüm sebebi.

\section{Giriş}

Ölüm zamanı adli makamlarca adli tıp uzmanlarına sıkça sorulan sorulardan biridir. Günümüzde ölüm zamanı ile ilgili olarak pek çok araştırma yapılmış olmakla birlikte, uygulamada postmortem değişimler ve vitröz sıvı $\mathrm{K}^{+}$değeri dışında çok fazla yöntem kullanılmamaktadır (1-5). Postmortem vücut sıvılarındaki biyokimyasal değişkenler, ölümden sonra geçen süre ve ölümün türüne bağlı olarak değişiklik gösterebilmektedir. Göz içi sıvısı, çok iyi korunması, kontaminasyon riskinin az oluşu, postmortem kimyasal değişimlerin yavaş olması ve kolay elde edilebilmesi nedeniyle postmortem interval tayininde sıkça kullanılmaktadır. Özellikle postmortem interval (PMİ) tayininde, vitröz sıvı $\mathrm{K}^{+}$

Sorumlu Yazar: Doç. Dr. Kenan Karbeyaz

Eskişehir Adli Tıp Şube Müdürlüğü

E-mail: drkenankarbeyaz@hotmail.com

\section{Abstract}

Objective: The time of the death has been one of the questions frequently inquired by courts to the forensic medicine experts. In this study, it is aimed to investigate the relationship between cause of death and postmortem interval with can easily be detected in postmortem intraocular fluid samples and routine biochemical tests.

Materials and Methods: A total of 100 cases autopsied at the Eskisehir Osmangazi University whose exact times of the death were known have been included in the study. Cases were divided into 3groups as 10 hour and below postmortem interval, 10-20 hours and upon 20 hours. The cause of death was divided into two groups as traumatic and non-traumatic.

Results and Conclusion: In this study the significant relationship was determined between potassium and uric acid levels and postmortem interval. It is determined that the mean level of Sodium and Chlorine sow difference in patients died because of traumatic and non-traumatic reasons.

Keywords: Postmortem biochemistry, Vitreous humor, Time since death, Cause of death.

tayini anlamlı bulunmuş ve bu konuda formüller geliştirilmiştir (7-9).Vitröz elektrolitler, glukoz ve üre nitrojeninin rutin incelemelerinin ölüm nedeni ve ölüm zamanının belirlenmesinde yardımcı olduğu belirtilmektedir (2-6).

$\mathrm{Bu}$ çalışmada, postmortem göz içi sıvı örneklerinde, rutin biyokimyasal incelemelerde kolaylıkla tetkik edilebilen Sodyum, Potasyum, Klor, Glukoz, Laktat Dehidrojenaz (LDH), Amilaz, ve Ürik asit düzeylerinin ölüm nedeni ve postmortem interval ile ilişkisini araştırmak amaçlanmıştır.

\section{Gereç ve Yöntem}

Eskişehir Osmangazi Üniversitesi Morgunda 2005 yılında yaklaşık bir yılı kapsayan dönemde, otopsisi yapılan ve kesin ölüm zamanı kesin olarak bilinen 100 olgu çalışma kapsamına alınmıştır. Olgulardan göz içi sıvısı, steril enjektörle gözün dış açısı hizasından $45{ }^{\circ}$ lik açıyla yavaş yavaş aspire edilerek alınmıştır. Aspire edilen yere gözün doğal görüntüsünün bozulmaması için serum fizyolojik enjekte edilmiştir. Alınan 
örneklerde Sodyum, Potasyum, Klor, Glukoz, LDH, Amilaz ve Ürik asit, düzeyleri incelenmiştir. Bu biyokimyasal parametreler, her laboratuvarda kolayca ölçülebileceği ve uygulanabilir oldukları için seçilmiştir. Göz içi sıvısındaki biyokimyasal analizler Osmangazi Üniversitesi Tıp Fakültesi Biyokimya Anabilim Dalında, Hitachi 911 marka otoanalizörde, Bohreinger Mannhaim original kitleri kullanılarak gerçekleştirilmiştir. Otopsi esnasında alınan örnekler, en fazla 30 dakika içinde biyokimya laboratuvarına ulaştırılmıştır. Bu arada herhangi bir muhafaza yöntemi kullanılmamıştır. Otopsi salonu sıcaklığı, mevsim farkı olmaksızın 18-20 derece olarak kaydedilmiştir. Örneklerin otopsi işlemi esnasında alınma saati ile tetkik saati arasında minimum 20 dakika maksimum 30 saat, ortalama 7 saat süre geçmiştir. Laboratuvar ortamında örnekler, koruyucu kullanılmaksızın,-4 derece buzdolabında muhafaza edilmiştir.

Örneklerin alındığ 1 olgularda $(n=100)$, kişinin yaşı, cinsiyeti, ölüm nedeni, ölüm zamanı ve yakınlarından alınan anamneze göre özgeçmişinde herhangi bir kronik hastalık olup olmadı̆̆ 1 gibi bilgiler bir veri toplama formuna kaydedilmiştir.

Olgular, ölüm zamanı açısından, postmortem intervali 10 saat ve altı, 11-20 saat ve 20 saatin üstünde olanlar şeklinde 3 gruba ayrılmıştır. Gruplandırma yapılırken, hastane ve olay yeri kayıtları ile postmortem makroskobik değişiklikler dikkate alınmış, kesin ölüm zamanı bilinen olgular çalışmaya dâhil edilmiştir. Ölüm nedeni açısından travmatik ve travmatik olmayan ölümler olarak 2 gruba ayrılmıştır. Göz içi sıvısında incelenen değişkenlerin postmortem interval ile ilişkisini değerlendirmek için pearson korelasyon analizi yapılmıştır. Ölüm zamanı açısından 3 gruba ayrılan olgular arasında karşılaştırmalı varyans analizi yapılmıştır. Travmatik ve travmatik olmayan nedenle ölen olgu gruplarında biyokimyasal değişimler açısından farklılık olup olmadığını değerlendirmek için "independent sample t" testi uygulanmıştır.

\section{Bulgular}

Toplam 100 olgunun 58'i erkek, 42'si kadındır. Olguların en küçügüu 2 yaşında, en büyüğü 89 yaşında olup, yaş ortalaması $55.0 \pm 20.3$ olarak saptanmıştır (median 60.5, mod 55).

İncelenen değişkenlerin postmortem interval ile ilişkileri

Olguların postmortem intervale göre dağılımları Tablo 1'de sunulmuştur.

Tablo 1. Olguların postmortem intervale göre dağılımları.

\begin{tabular}{|l|c|}
\hline Postmortem İnterval & $\begin{array}{c}\text { Olgu } \\
\text { saysı }\end{array}$ \\
\hline $0-600$ dakika (0-10 saat) & 48 \\
\hline 601-1200 dakika (10-20 saat) & 35 \\
\hline 1201 dakikadan fazla (20 saatten fazla) & 17 \\
\hline Toplam & $\mathbf{1 0 0}$ \\
\hline
\end{tabular}

Tablo 2. Postmortem intervali 10 saat ve altında olanlarla 10-20 saat arası olanların vitreous humor değerlerinin karşılaştırılması.

\begin{tabular}{|c|c|c|c|}
\hline & \multicolumn{2}{|c|}{ Postmortem İnterval (PMI) } & \multirow[b]{2}{*}{ P Değeri } \\
\hline & $\begin{array}{c}\text { PMI } \leq 600 \text { dakika } \\
\text { (Grup 1) }\end{array}$ & $\begin{array}{c}\text { PMI }>600 \leq 1200 \text { dakika } \\
\text { (Grup 2) }\end{array}$ & \\
\hline $\begin{array}{l}\text { Sodyum Min.-Mak. } \\
(\mathrm{mmol} / \mathrm{L}) \quad \text { Ort. } \pm \mathrm{SD}\end{array}$ & $\begin{array}{l}92.00-162.00 \\
123.71 \pm 13.17\end{array}$ & $\begin{array}{l}90.00-158.00 \\
120,87 \pm 13.38\end{array}$ & $\mathrm{P}>0,05$ \\
\hline $\begin{array}{l}\text { Potasyum Min.-Mak.. } \\
(\mathrm{mmol} / \mathrm{L}) \quad \text { Ort. } \pm \mathrm{SD}\end{array}$ & $\begin{array}{l}4.60-7.00 \\
5.15 \pm 1.34\end{array}$ & $\begin{array}{l}5.20-13.80 \\
7.87 \pm 1.69\end{array}$ & $\mathrm{P}<0.001$ \\
\hline $\begin{array}{l}\text { Na/K oranı Min_Mak.. } \\
\text { Ort. } \pm \text { SD }\end{array}$ & $\begin{array}{l}12.43-53.08 \\
27.37 \pm 9.02\end{array}$ & $\begin{array}{l}10.02-34.28 \\
17.92 \pm 4.60\end{array}$ & $\mathrm{P}<0.001$ \\
\hline $\begin{array}{l}\text { Klor Min-Mak.. } \\
(\mathrm{mmol} / \mathrm{L}) \quad \text { Ort. } \pm \mathrm{SD}\end{array}$ & $\begin{array}{l}95.00-131.00 \\
114.97 \pm 9.38\end{array}$ & $\begin{array}{l}94.00-148.00 \\
114.09 \pm 11.81\end{array}$ & $\mathrm{P}>0,05$ \\
\hline $\begin{array}{l}\text { Glukoz Min-Mak. } \\
(\mathrm{mmol} / \mathrm{L}) \quad \text { Ort. } \pm \mathrm{SD}\end{array}$ & $\begin{array}{l}64.50-94.98 \\
0.00 \pm 451.00\end{array}$ & $\begin{array}{l}59.94-63.23 \\
0.00 \pm 232.00\end{array}$ & $\mathrm{P}>0,05$ \\
\hline $\begin{array}{l}\text { LDH Min-Mak.. } \\
(\mathrm{mmol} / \mathrm{L}) \quad \text { Ort. } \pm \mathrm{SD}\end{array}$ & $\begin{array}{l}13.00-2023.00 \\
389.52 \pm 496.98\end{array}$ & $\begin{array}{l}24.00-1815.00 \\
391.85 \pm 502.44\end{array}$ & $\mathrm{P}>0,05$ \\
\hline $\begin{array}{l}\text { Amilaz Min-Mak } \\
(\mathrm{mmol} / \mathrm{L}) \quad \text { Ort. } \pm \mathrm{SD}\end{array}$ & $\begin{array}{l}0.0-11.00 \\
3.07 \pm 2.73\end{array}$ & $\begin{array}{l}0.00-12.00 \\
3.22 \pm 2.70\end{array}$ & $\mathrm{P}>0,05$ \\
\hline $\begin{array}{l}\text { Ürik asit Min-Mak. } \\
(\mathrm{mmol} / \mathrm{L}) \quad \text { Ort. } \pm \mathrm{SD}\end{array}$ & $\begin{array}{l}0.10-3.80 \\
1.03 \pm 0.91\end{array}$ & $\begin{array}{l}0.30-5.20 \\
1.52 \pm 0.97\end{array}$ & $\mathrm{P}>0,05$ \\
\hline $\begin{array}{l}\text { UA/K oranı Min.-Mak. } \\
(\mathrm{mmol} / \mathrm{L}) \quad \text { Ort. } \pm \mathrm{SD}\end{array}$ & $\begin{array}{l}0.01-0.61 \\
0.19 \pm 0.14\end{array}$ & $\begin{array}{l}0.04-0.40 \\
0.20 \pm 0.11\end{array}$ & $\mathrm{P}>0,05$ \\
\hline
\end{tabular}


Tablo 3. Postmortem intervali 10-20 saat arası olanlarla 20 saat ve üzerinde olanların vitreous humor değerlerinin karşılaştırılması.

\begin{tabular}{|c|c|c|c|}
\hline & \multicolumn{2}{|c|}{ Postmortem İnterval (PMI) } & \multirow[b]{2}{*}{ P Değeri } \\
\hline & $\begin{array}{c}\text { PMI }>600 \leq 1200 \text { dakika } \\
(\text { Grup } 2)\end{array}$ & $\begin{array}{c}\text { PMI }>1200 \text { dakika } \\
(\text { Grup 3) }\end{array}$ & \\
\hline $\begin{array}{l}\text { Sodyum Min.-Mak.. } \\
(\mathrm{mmol} / \mathrm{L}) \quad \text { Ort. } \pm \mathrm{SD}\end{array}$ & $\begin{array}{l}90.00-158.00 \\
120,87 \pm 13.38\end{array}$ & $\begin{array}{l}71.00-151.00 \\
109.08 \pm 20.50\end{array}$ & $\mathrm{P}>0,05$ \\
\hline $\begin{array}{l}\text { Potasyum Min.-Mak.. } \\
(\mathrm{mmol} / \mathrm{L}) \quad \text { Ort. } \pm \mathrm{SD}\end{array}$ & $\begin{array}{l}5.20-13.80 \\
7.87 \pm 1.69\end{array}$ & $\begin{array}{l}5.70-16.30 \\
11.93 \pm 3.38\end{array}$ & $\mathrm{P}<0.001$ \\
\hline $\begin{array}{l}\mathrm{Na} / \mathrm{K} \text { oranı Min_Mak.. } \\
\text { Ort. } \pm \text { SD }\end{array}$ & $\begin{array}{l}10.02-34.28 \\
17.92 \pm 4.60\end{array}$ & $\begin{array}{l}4.36-26,38 \\
12.07 \pm 5.65\end{array}$ & $\mathrm{P}<0.01$ \\
\hline $\begin{array}{l}\text { Klor Min-Mak.. } \\
(\mathrm{mmol} / \mathrm{L}) \quad \text { Ort. } \pm \mathrm{SD}\end{array}$ & $\begin{array}{l}94.00-148.00 \\
114.09 \pm 11.81\end{array}$ & $\begin{array}{l}78.00-133.00 \\
111.33 \pm 14.58\end{array}$ & $\mathrm{P}>0,05$ \\
\hline $\begin{array}{l}\text { Glukoz Min-Mak. } \\
(\mathrm{mmol} / \mathrm{L}) \quad \text { Ort. } \pm \mathrm{SD}\end{array}$ & $\begin{array}{l}59.94-63.23 \\
0.00 \pm 232.00\end{array}$ & $\begin{array}{l}25.75-27.40 \\
0.00 \pm 125.00\end{array}$ & $\mathrm{P}>0,05$ \\
\hline $\begin{array}{l}\text { LDH Min-Mak.. } \\
(\mathrm{mmol} / \mathrm{L}) \quad \text { Ort. } \pm \mathrm{SD}\end{array}$ & $\begin{array}{l}24.00-1815.00 \\
391.85 \pm 502.44\end{array}$ & $\begin{array}{l}18.00-1993.00 \\
359.25 \pm 426.05\end{array}$ & $\mathrm{P}>0,05$ \\
\hline $\begin{array}{l}\text { Amilaz Min-Mak } \\
(\mathrm{mmol} / \mathrm{L}) \quad \text { Ort. } \pm \mathrm{SD}\end{array}$ & $\begin{array}{l}0.00-12.00 \\
3.22 \pm 2.70\end{array}$ & $\begin{array}{l}0.00-10.00 \\
2.75 \pm 2.94\end{array}$ & $\mathrm{P}>0,05$ \\
\hline $\begin{array}{l}\text { Ürik asit Min-Mak. } \\
(\mathrm{mmol} / \mathrm{L}) \quad \text { Ort. } \pm \mathrm{SD}\end{array}$ & $\begin{array}{l}0.30-5.20 \\
1.52 \pm 0.97\end{array}$ & $\begin{array}{l}0.80-6.70 \\
3.52 \pm 1.85\end{array}$ & $\mathrm{P}<0.001$ \\
\hline $\begin{array}{l}\text { UA/K oranı Min.-Mak. } \\
(\mathrm{mmol} / \mathrm{L}) \quad \text { Ort. } \pm \mathrm{SD}\end{array}$ & $\begin{array}{l}0.04-0.40 \\
0.20 \pm 0.11\end{array}$ & $\begin{array}{l}0.08-0.58 \\
0.31 \pm 0.14\end{array}$ & $\mathrm{P}>0,05$ \\
\hline
\end{tabular}

Tablo 4. Postmortem intervali 10 saat ve altında olanlarla 20 saat ve üzerinde olanların vitreous humor değerlerinin karşılaştırılması.

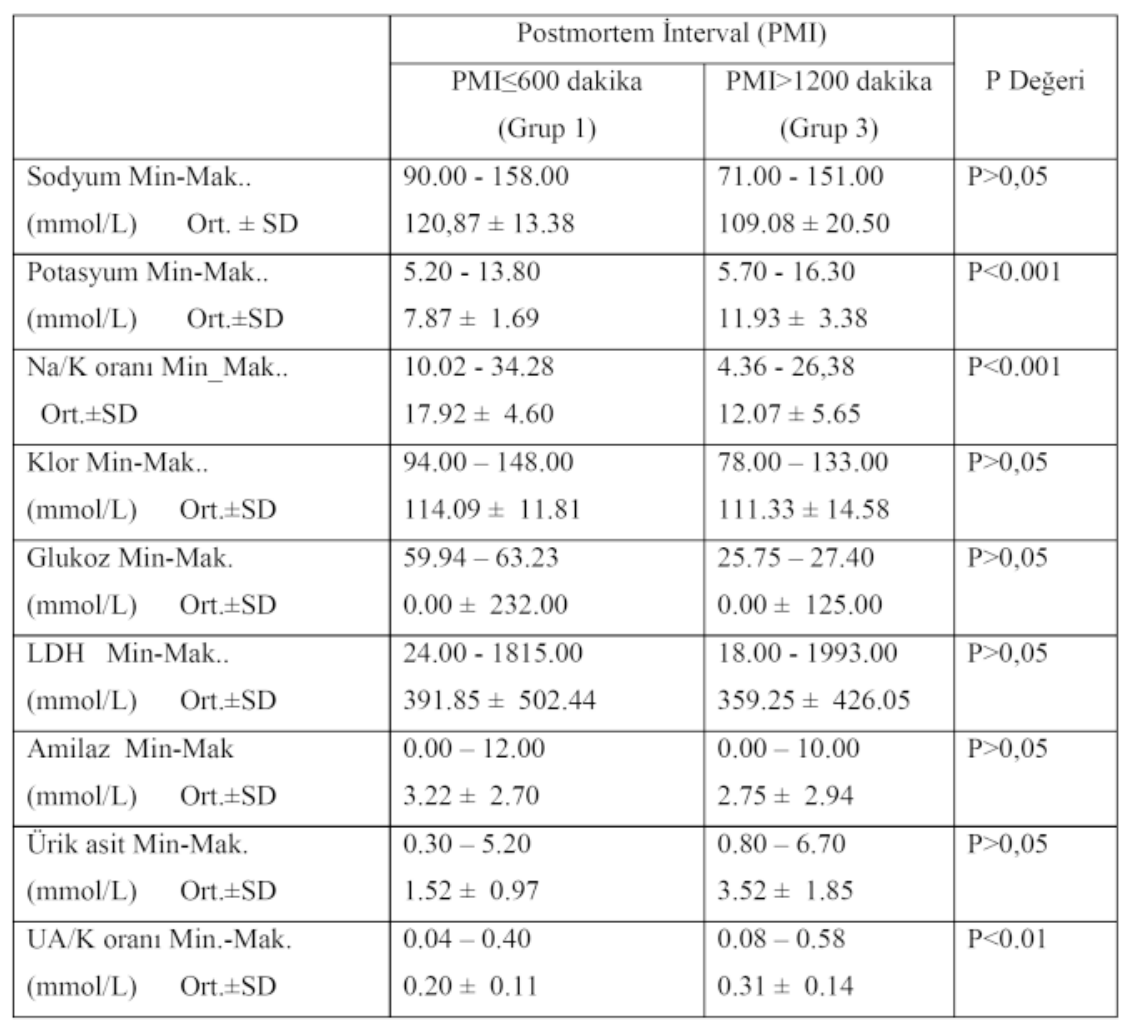

Na: Sodyum, K: Potasyum, UA: Ürik asit, Min-Mak: Minimum-Maksimum, SD:Standart sapma 
Postmortem interval arttıkça potasyum seviyesinde istatistiksel olarak anlamlı bir yükselme olduğu saptandı $(\mathrm{P}<0,001)$. Sodyum, klor, glukoz, LDH, amilaz seviyelerinde anlamlı bir değişiklik görülmedi. PMİ süresi 20 h’ten fazla olan olgulardaki ürik asit seviyesinin PMİ süresi daha az olan olgulara göre anlamlı bir şekilde yüksek olduğu saptandı
$(\mathrm{P}<0,001)$. Yapılan analizde PMİ ile potasyum, ürik asit ve Ürik asit/Potasyum oranı arasında pozitif bir ilişki olduğu, Sodyum/Potasyum oranı arasında negatif bir ilişki olduğu saptandı. Zaman ayrımı yapılmaksızın tüm olgular dikkate alındığında, göz içi sıvısı ortalama glukoz düzeyi $55.04 \pm 7.98$ $\mathrm{mg} / \mathrm{dl}$ ölçüldü.

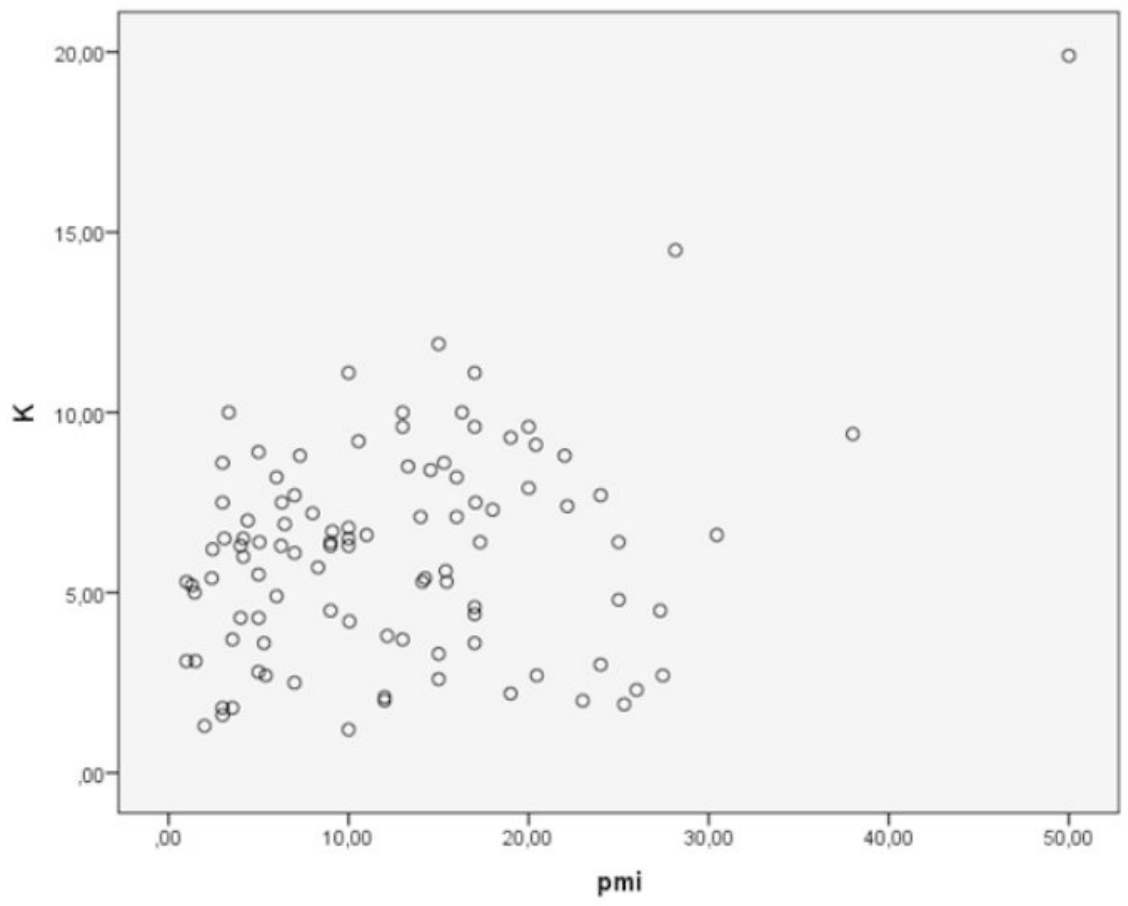

Grafik 1. Postmortem intervalde Potasyum seviyesinin değişimi.

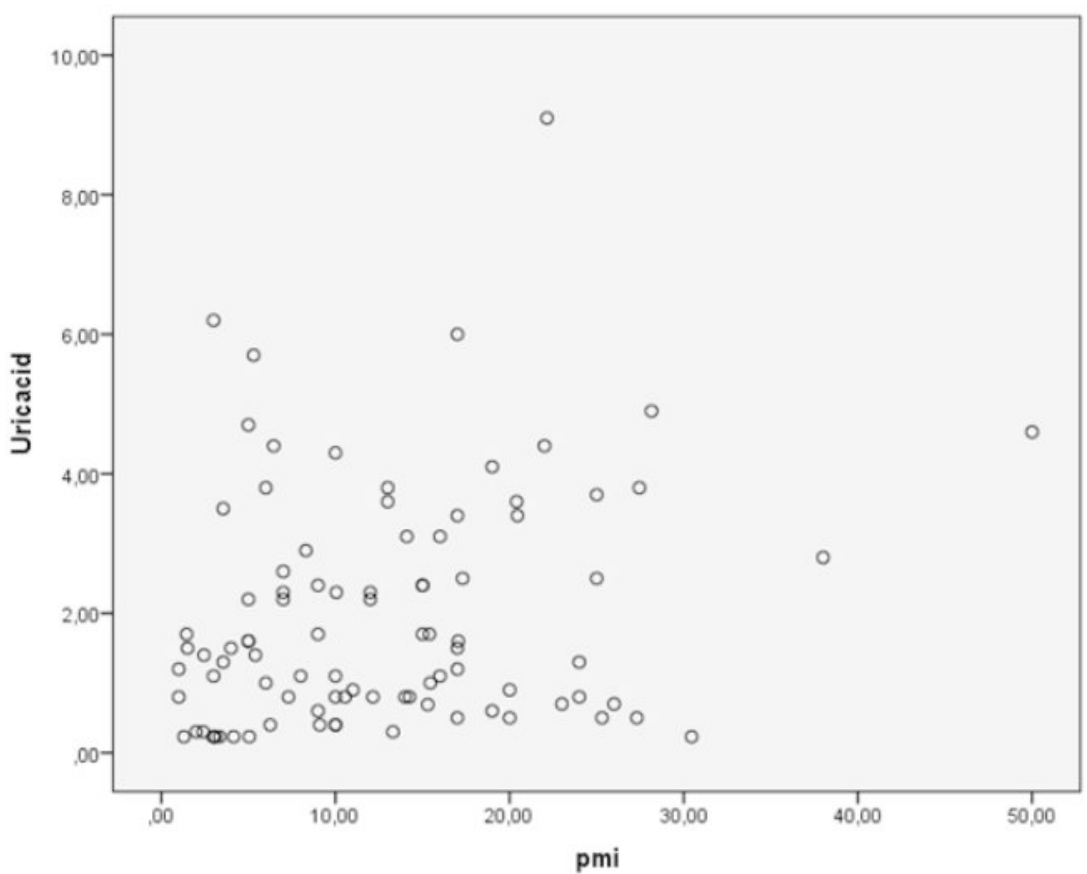

Grafik 2. Postmortem intervalde Ürik asit seviyesinin değişimi. 
Her ne kadar PMI gruplarına göre $\mathrm{K}$ ve ürik asit ortalama değerlerinde anlamlı farklılık saptanmış ise de, PMI değerlerine göre $\mathrm{K}$ ve ürik asit için scatter grafik yapıldığında bu değerlerin PMI belirlemede çok belirleyici olmadıkları anlaşılmaktadır (Grafik 1,2).

İncelenen değişkenlerin ölüm türü/nedeni ile ilişkileri

Olguların 30'u travmatik bir nedenle, 70’i travmatik olmayan bir nedenle ölen olgulardır. Göz içi sıvısında incelenen değişkenlerin travmatik nedenle ölen (Grup 1) ve travmatik olmayan nedenle ölen (Grup 2) olgu gruplarına göre değişimi Tablo 5’te gösterilmiştir.

Göz içi sıvısında Sodyum ve Klorun ortalama değerleri travmatik nedenle ve travmatik olmayan nedenle ölenlerde farklılık arz etmektedir. Sodyum ve Klorun ortalama değerleri travmatik nedenle ölenlerde diğer gruba göre daha düşük saptanmıştır.

Tablo 5. Göz içi sıvısında incelenen değişkenlerin travmatik nedenle ve travmatik olmayan nedenle ölen olgu gruplarına göre değişimi.

\begin{tabular}{|l|l|l|l|}
\hline \multirow{2}{*}{} & \multicolumn{2}{|l|}{} & \\
\cline { 2 - 4 } & $\begin{array}{l}\text { Ölüm nedeni } \\
\text { Grup 1 } \\
\text { Travmatik } \\
(n=30)\end{array}$ & $\begin{array}{l}\text { Grup 2 } \\
\text { Travmatik olmayan } \\
(n=70)\end{array}$ & P \\
\hline Sodium $(\mathrm{mEq} / \mathrm{L})$ & $122.43 \pm 36.37$ & $100.84 \pm 43.72$ & .013 \\
\hline Potassium $(\mathrm{mEq} / \mathrm{L})$ & $6.90 \pm 2.55$ & $5.81 \pm 3.18$ & .100 \\
\hline Clor $(\mathrm{mEq} / \mathrm{L})$ & $106.33 \pm 28.04$ & $85.81 \pm 33.04$ & .002 \\
\hline Glucose $(\mathrm{mg} / \mathrm{dl})$ & $62.40 \pm 85.58$ & $51.75 \pm 75.69$ & .540 \\
\hline Lactat Dehydrogenase $(\mathrm{U} / \mathrm{L})$ & $490.03 \pm 637.44$ & $785.66 \pm 1467.81$ & .292 \\
\hline Amylase $(\mathrm{U} / \mathrm{L})$ & $3.62 \pm 4.24$ & $3.10 \pm 2.82$ & .543 \\
\hline Uric acid $(\mathrm{mg} / \mathrm{dl})$ & $2.00 \pm 2.06$ & $1.93 \pm 1.55$ & .862 \\
\hline
\end{tabular}

\section{Tartışma}

Postmortem kan, serebrospinal sıvı, vitröz sıvı, perikardiyal sıvı ve diğer vücut sıvılarının biyokimyasal incelemelerinin ölüm zamanının ve ölüm sebebinin belirlenmesinde yardımc olduğu belirtilmektedir (1-6). Göz içi sıvısındaki biyokimyasal incelemelerle ilgili literatürler incelendiğinde araştırmaların çoğunluğunun postmortem interval ile ilgili olduğu görülmüştür (1-6,10-15).

Vitröz sıvı, elektrolitlerin konsantrasyonlarının ölümden sonra geçen süre ile istatistiksel olarak anlamlı bir değişim gösterdiği, $\mathrm{K}^{+}$konsantrasyonunun ölüm zamanı ile direk ilişkisi olduğu bildirilmektedir $(3,16-20)$. Bu çalışmada da, postmortem interval arttıkça potasyum seviyesinde istatistiksel olarak anlamlı bir yükselme olduğu saptanmıştır $(\mathrm{P}<0,001)$. Sodyum, klor, glukoz, LDH, amilaz değerleri ile postmortem interval arasında anlamlı ilişki saptanmamıştır. PMİ süresi 20 h'ten fazla olan olgulardaki ürik asit seviyesinin PMİ süresi daha az olan olgulara göre anlamlı bir şekilde yüksek olduğu saptandı $(\mathrm{P}<0,001)$. Yapılan analizde PMİ ile potasyum, ürik asit ve Ürik asit/Potasyum oranı arasında pozitif bir ilişki olduğu, Sodyum/Potasyum oranı arasında negatif bir ilişki olduğu saptanmıştır.

Jashnani ve arkadaşları (3), postmortem interval açısından, göz içi sıvısında, potasyum, sodyum, kalsiyum ve klor üzerinde çalışmış, potasyum değeri dışında, post mortem interval ile göz içi sıvısındaki sodyum, kalsiyum ve klor arasında bir ilişki bulamadıklarını bildirmişlerdir. Postmortem göz içi potasyum seviyesinin lineer bir artış gösterdiğini, saatte 0,929 mmol/L artış gösterdiğini belirtmişlerdir. Sturner ve Gantner (21), 1964 yılında postmortem interval tespiti için göz içi sıvısındaki potasyum değerine ait PMI (hours) $=\left(7,14 \mathrm{xK}^{+}\right)-39,1$ formülünü yayınlamışlardır. Daha sonra Later ve Madea (22), PMI (hours) $=\left(5,26 \mathrm{xK}^{+}\right)-30,9$ formülünü kullanmışlardır. Ancak bu formüllerin pratik kullanımda yanlış sonuç verebildikleri bildirilmiştir. Sunulan çalışmada göz içi sıvısında incelenen potasyumun (K) en düşük değeri 4,60 mmol/L, en yüksek değeri 16,30 mmol/L ölçülmüş, ölümden sonra geçen süre arttıkça ortalama potasyum (K) değerlerinin arttığ görülmüsştür.

Çalışmamızda, her ne kadar PMI gruplarına göre K ve ürik asit ortalama değerlerinde anlamlı farklılık saptanmakla birlikte PMI değerlerine göre $\mathrm{K}$ ve ürik asit için scatter grafik yapıldığında bu değerlerin PMI belirlemede çok belirleyici olmadıkları anlaşılmaktadır.

$\mathrm{Na}$ düzeyinin, erken postmortem dönemde göreceli değişiklik göstermekle birlikte, normal serum konsantrasyon değerlerine benzerlik gösterdiği bildirilmiştir $(2,19)$. Jashnani ve arkadaşları postmortem göz içi sıvısı sodyum seviyesi ile 
ölüm zamanı arasında bir korelasyon bulamadıklarını bildirmişlerdir (3). Çalışmamızda postmortem interval ile göz içi sıvısı Na düzeylerinde anlamlı fark bulunamamıştır ( 0.05 ). Kesin ölüm zamanı belli tüm olgularda ortalama Na düzeyi 92$151 \mathrm{mmol} / \mathrm{L}$ arasında bulunmuştur.

Yapılan çalışmalarda göz içi sıvısındaki $\mathrm{Cl}$ düzeyinin erken postmortem dönemde minimal bir düşme göstereceği bildirilmiştir (11). Chandrakanth ve arkadaşları postmortem $\mathrm{Cl}$ değerinde anlamlı bir değişiklik olmadığını belirtmişlerdir (2). $\mathrm{Bu}$ çalışmada postmortem interval zamanı 10 saat ve altında olan vakalarda ortalama $\mathrm{Cl}$ değeri $114,97 \pm 9,38 \mathrm{mmol} / \mathrm{L}$ ölçülmüştür. Klorun serum konsantrasyonu tüm olgularda 95-133 mmol/Larasında olup literatürü destekler niteliktedir.

Göz içi sıvısında çalışlan diğer biyokimyasal incelemelerle postmortem interval arasında ilişki saptanamadı.

Postmortem biyokimyasal değerlerin ölüm türlerine göre farklılık gösterebildiği belirlenmiştir (22-29). Göz içi sıvısı glukoz düzeyinin, serumdakinin yarısı kadar olduğu ve diyabetik olmayanlarda göz içi sıvısı glukoz düzeyinin ölümden sonra birkaç saat içinde sıfıra doğru düşmekte olduğu, ayrıca diyabetik-nondiyabetik hasta ayırımında kullanılabileceği belirtilmiştir $(23,24)$. Bu çalışmada göz içi sıvısı ortalama glukoz düzeyi $55.04 \pm 7.98 \mathrm{mg} / \mathrm{dl}$ ölçüldü. Glukoz düzeyinin, ölümden sonra 10 saat ve daha az süre geçen olgularda sıfır düzeyine düştüğü görüldü. Bu iki sonuç ta literatürle uyumluydu. Glukozun ölçülen maksimum değeri $451 \mathrm{mg} / \mathrm{dl}$ ise, o vakanın diyabet olması ihtimalini düşündürdü. Ancak elimizde öyle bir veriyoktu.

Kawamoto ve arkadaşlarının (25) postmortem perikardiyal sıvı ile yaptıkları çalı̧mada, künt travma sonucu ölümlerde total protein ve albuminin düşük, ürik asit ve kreatinin yüksek olduğu belirtilmiştir. Tanskanen ve ark. (26), Finlandiya'da 1972-1992 y1lları arasında, intiharlar sonrası postmortem serum total kolesterol seviyesinin ölçüldü̆gü 176 olguyu içeren bir çalışmada, ası, ateşli silah, kesici-delici aletler ile olan intiharları bir gruba, ilaç intoksikasyonu, gaz zehirlenmesi, suda boğulmalar ile olan intiharları farklı bir gruba ayırmışlardır. Çalışma sonucunda ası, ateşli silah, kesici-delici aletler ile olan intiharlar $(\mathrm{N}=130)$ ile yüksek serum total kolesterol konsantrasyonu arasında pozitif ilişki olduğunu saptamışlardır. Maeda ve arkadaşları $(28,30)$ postmortem moleküler biyolojik analizlerin ölümün patofizyolojisini açıklamada yararlı olduğunu saptamışlardır. Mendelson ve ark. (31), ani travmatik nedenle ölen 28 erkek hastada postmortem kanda serum luteinizing hormon düzeylerini çalısmışlar, ateşli silah, ası, fizik mücadele sonrası olan ölümlerde serum luteinizing hormon düzeylerini yüksek bulmuşlar ve postmortem serum luteinizing hormon düzeylerinin bu tür ölümlerde biyolojik bir gösterge olabileceğini bildirmişlerdir. Yine doğal ölümler ve zorlamalı ölümler olarak iki gruba ayrılan bir başka çalışmada perikardiyal sıvıda üre, kreatinin, glukoz, kreatin kinaz 2, protein, kalsiyum, sodyum ve potasyum çalışılmış, üre haricinde çalışlan parametreler ile doğal ölüm ve zorlamalı

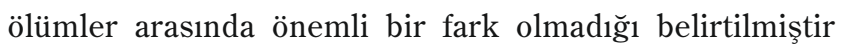
$(\mathrm{p}<0.05)$ (27).Li Zhu ve ark. (32), iskelet kası hasarı olan ve hipoksi, sıcak ve agonal konvülziyon nedeniyle ölen 395 adli otopsi vakasında, ölümün patofizyolojisini araştırmak için kan üre azotu ile karşılaştırmalı olarak postmortem serum ürik asit ve kreatinin seviyelerini çalışmışlardır. Özellikle termal etkiye bağlı akut ölümlerdeki hiperüriseminin ilerlemiş hipoksiyi gösterebileceği ve yükselmiş kreatinin düzeyinin iskelet kası hasarını yansıtabileceğini ileri sürmüşlerdir. İskelet kaslarında crush sendromunda veya ağır akut hasar durumlarında miyoglobin, potasyum, fosfat, organik asit, ürik asit ve kreatinin hücrelerden plazmaya salındığı ve fazlalığın idrarla atıldığı, fosfat ve sülfat derivelerinin idrarla atılımının potasyumda olduğu gibi kas hücrelerinin hücre içi katabolizması sonucu diğer plazma konsantrasyonlarının düşmesine rağmen orta derecede arttığı bildirilmiştir (33). Bu çalışmada; göz içi sıvısında Sodyum ve Klor ortalama değerlerinin travmatik nedenle ve travmatik olmayan nedenle ölenlerde farklılık arz ettiği, Sodyum ve Klorun ortalama değerlerinin travmatik nedenle ölen olgu grubunda diğer gruba göre daha düşük olduğu saptanmıştır. Brion ve ark. (27)'nın çalışmasında zorlamalı ve zorlamalı olmayan ölümlerde sodyum değeri açısından farklılık saptanmazken, çalışmamızda travmatik nedenle ölenlerde ortalama sodyum değerinin diğer gruba göre düşük olduğu saptanmıştır.

Göz içi sıvısı daha korunaklı olduğundan, postmortem biyokimyasal incelemeler açısından önemlidir. Sunulan çalışmada, potasyum ve ürik asit ortalama değerleri ile postmortem interval grupları arasında anlamlı bir ilişki olduğu saptanmıştır. Ancak bu anlamlılık, kesin olarak ölüm zamanının belirlenmesi açısından yeterli değildir. Ölüm zamanının kesin olarak belirlenmesini sağlayacak bir yöntem olmadığı, eldeki tüm verilerin birlikte değerlendirilmesine ihtiyaç olduğu düşünülmektedir. Sodyum, Klor, Glukoz, LDH ve Amilaz değerleri ile postmortem interval arasında anlamlı ilişki saptanmamıştır. Sodyum ve Klorun ortalama değerlerinin travmatik nedenle ölen olgu grubunda non-travmatik nedenle ölenlere göre daha düşük olduğu saptanmıştır.

Bu çalışmada olgu sayısının azlığı, otopsi işlemi esnasında alınan örneklerin laboratuvara ulaştırılması ve laboratuvarda bekleme sürelerinin standardize edilememiş olması çalışmanın kısıtllı̆ı̆ı olarak değerlendirilmiştir. Postmortem ayırıcı tanı ve PMİ hesaplanması ile ilgili bilgilerimize daha fazla katkı sağlaması açısından, ortam ile ilgili ısıya ait 
değişimlerin de dikkate alınarak farklı ölüm türlerini yansitacak şekilde olgu sayısı arttırılarak, laboratuvar desteği açısından en uygun biyokimyasal inceleme yöntemi araştırılarak bu yöndeki çalışmaların sürdürülmesi uygun olacaktır. Özellikle ürik asit değerleri açısından yeni çalışmalara ihtiyaç vardır.

\section{Kaynaklar}

1. Young ST, Wells JD, Hobbs GR, Bishop CP.Estimating post mortemintervalusing RNA degradation and morphological changes in tooth pulp.Forensic Sci Int. 2013;229(1-3):163 PMID: 23647867

2. Chandrakanth HV, Kanchan T, Balaraj BM, Virupaksha HS, Chandrashekar TN. Postmortem vitreous chemistry--an evaluation of sodium, potassium and chloride levels in estimation of time since death (during the first $36 \mathrm{~h}$ after death). J Forensic Leg Med.2013;20(4):211-6 PMID:23622461

3. Jashnani KD, Kale SA, Rupani AB. Vitreous humor: biochemical constituents in estimation of postmortem interval. J Forensic Sci. 2010;55(6):1523-7. PMID: 20666922

4. Madea B, Rödig A. Time of death dependent criteria in vitreous humor: accuracy of estimating the time since death. Forensic Sci Int. 2006; 20;164(2-3):87-92 PMID: 16439082

5. Thierauf A, Musshoff F, Madea B. Post-mortem biochemical investigations of vitreous humor. Forensic Sci Int. 2009 Nov 20;192(1-3):78-82 PMID: 19729257

6. Garg V, Oberoi SS, Gorea RK, Kiranjeet K. Changes in the levels of vitreous potassium with increasing time since death. JIAFM 2004;26(4): 136-9. ISSN 0971-0973

7. Hart AP, Zumwalt RE, Dasgupta A. Postmortem lipid levels for the analysis of risk factors of sudden death: usefulness of the Ektachem and Monarch analyzers. Am J Forensic Med Pathol 1997 Dec;18(4):354-359. PMID: 9430287

8. Gamero Lucas JJ, Romero JL, Ramos HM, Arufe MI, Vizcaya MA. Precision of estimatingtime of death by vitreouspotassiumcomparison of various equations.Forensic Sci Int. 1992 Oct;56(2):137-45. PMID: 1452104

9. Sparks D. L., Oeltgen P. R., Kryscio R. J., Hunsaker J. C. Comparison of chemical methods for determining postmortem interval. J Forensic Sci 1989; 34(1):197-206. PMID: 2918279

10. Balasooriya BA, St Hill CA, Williams AR. The biochemistry of vitreous humour. A comparative study of the potassium, sodium and urate concentrations in the eyes at identical time intervals after death.Forensic Sci Int. 1984;26(2):85-91. PMID: 6489885

11. Coe JI. Postmortem chemistry update. Emphasis on forensic application.Am J Forensic Med Pathol. 1993 Jun;14(2):91-117. PMID: 8328447

12. Lange N., Swearer S., Sturner W. Q. Human postmortem interval estimation from vitreous potassium; an analyis of original data from six different studies. Forensic Sci Int 1994;66:159-174. PMID: 7959466

13. Prasad BK, Choudhary A, Sinha JN. A study of correlation between vitreous potassium level and post mortem interval. Kathmandu Univ Med J 2003;1(2):132-4. PMID: 16388214

14. Ancan N. Dokgöz H, Yorulmaz C, Elmas İ. Fincancı SK. [In-vitro changes o f blood and postmortem interval] Adli Tip Bülteni 2000;5(2):83-7.
15. Kocatürk BK, Balcı Y, Bal C. [The evaluation of the findings of macroscopic eye examination with regard to post-mortem interval (PMI) in 2 cases known death time] Türkiye Klinikleri J Foren Med 2007;4(3):102-5 Turkish

16. Lie JT. Changes of potassium concentration in the vitreous humor after death. Am J Med Sci 1967;254(2):136-43. PMID: 4951791

17. Balasooriya B. A. W., St. Hill C. A., Williams A. R. The biochemical changes in precardial fluid after death. An investigation of the relationship between the time since death and the rise or fall in electrolyte and enzyme concentrations and their possible usefulness in determining the time of death. Forensic Sci Int 1984;26:93-102. PMID: 6489886

18. Coe J. I. Vitreous potassium as a measure of the postmortem interval: An historical review and critical evaluation. Forensic Sci Int 1989;42:201-213. PMID: 2676789

19. Coe J. I., Apple F. S. Variations in vitreous humour chemical values as a result of instrumentation. J Forensic Sci 1985;30(3):828-35. PMID: 4031810

20. Munoz JI, Suárez-Penaranda JM, Otero XL, Rodríguez-Calvo MS, Costas E, Miguens X, Concheiro L.A new perspective in the estimation of postmortem interval (PMI) based on vitreous. J Forensic Sci. 2001;46(2):209-14. PMID: 11305419

21. Sturner WQ, Gantner GE Jr. The postmortem interval. A study of potassium in the vitreous humor. Am J Clin Pathol 1964;42:137-44. PMID: 14202146

22. Madea B, Henssge C, Hçnig W, Gerbracht A. References for determining the time of death by potassium in vitreous humor. Forensic Sci Int 1989;40(3):231-43. PMID: 2731842

23. Knight B, editor. Forensic Pathology. $2^{\text {nd }}$ Edition. London Oxford University Press, 1996.

24. Madea B, Musshoff F. Postmortem biochemistry. Forensic Sci Int. 2007;165(2-3):165-71 PMID:16781101

25. Kawamoto O, Michiue T, Ishikawa T, Maeda H. Comprehensive evaluation of pericardial biochemical markers in death investigation.Forensic Sci Int. 2013;224(1-3):73-9 PMID: 23196195

26. Tanskanen A, Vartiainen E, Tuomilehto J, Viinamaki H, Lehtonen J, Puska P. High serum cholesterol and risk of suicide. Am J Psychiatry 2001 May; 158(5):824-5. PMID: 10739432

27. Brion F., Marc B., Launay F., Gailledreau J. and Durigon M.: Postmortem interval estimation by creatinine levels in human psoas muscle. Forensic Sci Int 1991;52:113-120. PMID: 1783334

28. Maeda H, Ishikawa $T$, Michiue $T$. Forensic biochemistry for functional investigation of death: concept and practical application.Leg Med (Tokyo). 2011;13(2):55-67.PMID: 21269863

29. Volaka A, Safran N, Kolusayın MÖ, İnce N, Yorulmaz E, İnce CH, et al. [C- reactive protein levels in postmortem period and its relationship between cause of death and time of death]. Adli Tip Dergisi 2011;25(2):85-97. Turkish

30. Maeda H, Zhu BL, Ishikawa T, Quan L, Michiue T. Significance of postmortem biochemistry in determining the cause of death.Leg Med (Tokyo). 2009;11(1):46-9. PMID:19269240

31. Mendelson JH, Dietz PE, Ellingboe J. Postmortem plasma luteinizing hormone levels and antemortem violence. Pharmacol Biochem Behav 1982; 17(1):171-3. PMID: 7122663

32. Zhu BL, Ishida K, Quan L, Taniguchi M, Oritani S, Li DR, et al. Postmortem serum uric acid and creatinine levels in relation to the causes of death. Forensic Sci. Int 2002 Jan 24;125(1):59-66. PMID: 11852203

33. Mason JK, Purdue BN. The Chemical Pathology of Trauma 3th Edition Baron DN, editor. The Pathology of Trauma. Oxford Universty Pres, Inc, New York 2000:399-400 p. 